\title{
THE EFFECT OF LED LIGHTING DOSAGE ON PHOTOSYNTHETIC INDICES IN TATSOI
}

\author{
Mantas Kačiušis ${ }^{1,2}$, Giedrè Samuolienè $\dot{1}^{1,2}$ \\ ${ }^{1}$ Lithuanian Research Centre for Agriculture and Forestry, Lithuania \\ ${ }^{2}$ Aleksandras Stulginskis University, Lithuania \\ mantas14kaunas@gmail.com
}

\begin{abstract}
Plant factories provide possibilities to get optimal yield of green leafy vegetables entire year independent from the season. The technology of light-emitting diode (LEDs) light has become one of the most powerful tools in photophysiological researches of various horticultural plants. In order to manage plant physiology and improve productivity, it is necessary to develop new LEDs technologies in horticulture. The aim of the study was to investigate different lighting intensities and elevated red light $(660 \mathrm{~nm})$ effect on tatsoi photosynthetic parameters. All plants were grown under the same light sources where overall photosynthetic photon flux density (PPFD) varied from 200 to $300 \mu \mathrm{mol} \mathrm{m} \mathrm{m}^{-2} \mathrm{~s}^{-1}$. Three days before harvesting red light intensity $(640$ and $660 \mathrm{~nm})$ was increased until $132 \mu \mathrm{mol}$ $\mathrm{m}^{-2} \mathrm{~s}^{-1}$ and $660 \mathrm{~nm}$ until $188 \mu \mathrm{mol} \mathrm{m} \mathrm{m}^{-2} \mathrm{~s}^{-1}$ at 16 hours photoperiod. In the last treatment merely 24 hours photoperiod was applied. The photosynthetic indices in tatsoi were determined by non-destructive methods using LI-6400XT portable photosynthesis system, OS5p fluorometer, DUALEX optical sensor and CID leaf spectrometer. Research was performed in $2017-2018$ winter season. The obtained data revealed that the total photosynthetic photon flux density (PPFD) at level of $200 \mu \mathrm{mol} \mathrm{m}{ }^{-2} \mathrm{~s}^{-1}$ was sufficient for optimal $\mathrm{CO}_{2}$ assimilation in tatsoi plants. The increased PPFD of LED light at pre-harvest stage resulted in reduced photosynthetic parameters of plants.
\end{abstract}

Key words: Brassica rapa, photosynthetic parameters, photosynthetic photon flux density, light-emitting diode.

\section{Introduction}

Light spectra and intensity are the main factors to promote efficient plant growth. The technology of light-emitting diodes (LEDs) provide possibility to change spectral characteristics and combine the desired light with respective wavelengths without unnecessary spectral parts (Olle \& Viršilè, 2013). The solid-state lighting technology has become a tremendous innovative and alternative instrument in horticulture. LEDs have a broad light spectrum, which can be tailored in various proportions and produce high light levels. The feature and possibility for light and environment management and digital controlling is one of the most useful advantages in vertical farming (Cocetta et al., 2017).

To promote and ensure effective and efficient photosynthetic process, the cultivation conditions should be optimized according to the plant natural needs. Different plant species and varieties have different optimal cultivation conditions (temperature, light intensity, light spectrum etc.) (Carvalho \& Folta, 2014). Some authors state that mild stress conditions can improve the productivity or nutritional value of green vegetables (Jansen et al., 2008; Rouphael et al., 2018).

Optimal spectrum characteristics and suitable qualitative composition have a direct impact on photosynthetic process (Kang et al., 2013; Wojciechowska et al., 2015). Zhen \& Van Iersel (2017) in experiments with lettuce observed spectrum quality impact on instantaneous photosynthetic intensity (Pn) and claimed far-red light influence on photosynthetic intensity. Moreover, red and far red light transfer energy to photosystem II (PS II) and excites electron transmission through energetic reactions (Muhoz \& Quiles, 2003).

Previous studies with pre-harvest showed that supplemental LED lighting a few days before harvesting in greenhouses, resulted in improved nutritional value of different green vegetables. One of the most analysed effects was nitrate reduction (Samuolienè et al., 2009; Samuolienè et al., 2011; Bliznikas et al., 2012). The decrease in nitrate contents was accompanied by increased levels of carbohydrates and ascorbic acid in vegetable tissues (Samuolienè et al., 2012a; Zhou, Liu, \& Yang, 2012; Wanlai, Liu, \& Qichang, 2013). From the practical side, these research findings also propose the ways how to improve the value of green vegetables, cultivated in light deficiency conditions. Nevertheless, there are no accomplished studies with elevated red light component intensity three days before harvesting, and the effect on photosynthesis system acclimatization and response is still clearly unknown in tatsoi.

Chlorophyll is the main pigment participating in photosynthetic process, which allows plants to absorb energy (Hall \& Rao, 1999). The nitrogen impact on photosynthesis is crucial. As the main component it promotes efficient photosynthetic process and improves all photosynthetic apparatus activity (Sun et al., 2016; Basi, Menossi, \& Mattiello, 2018). Photochemical reflectance index is used for tracking changes and variability in photosynthetic light use efficiency (Nakaji, Oguma, \& Fujinuma, 2006).

The efficiency of electrical energy utilization for lighting is a key parameter evaluating the costs of vegetable production in greenhouses and vertical farming system (Kubota et al., 2016). In addition to 
this, it is possible to apply lower PPFD in various horticulture systems. This is enough in order to grow plants without losses and sufficient for physiology needs, as well as allows to save energy costs (Singh et al., 2015).

\section{Materials and Methods}

The experiment was conducted in closed controlled-environment growth chamber at the Institute of Horticulture, Lithuanian Research Centre for Agriculture and Forestry. The investigation was carried out in 2017-2018 winter season. Day and night temperatures were set at $21 / 17^{\circ} \mathrm{C} \pm 2{ }^{\circ} \mathrm{C}$ respectively, the $16 \mathrm{~h}$ photoperiod was established. The relative air humidity in the growth chamber was approximately $50-60 \%$.

All plants were grown under the same spectral combination of light-emitting diode (LEDs) units at photosynthetic photon flux density (PPFD) levels at 200 and $300 \mu \mathrm{mol} \mathrm{m} \mathrm{m}^{-2} \mathrm{~s}^{-1}$ (Table 1). Three days before the harvest, the intensity of LED lighting was increased from 200 to $300 \mu \mathrm{mol} \mathrm{m} \mathrm{m}^{-2} \mathrm{~s}^{-1}$ by elevating the intensity of red light $(660 \mathrm{~nm})$ or of all spectral components proportionally at $16 \mathrm{~h}$ or 24 $\mathrm{h}$ photoperiod. The experiment scheme is presented below in Table 1.

All plants were grown in plastic trays (two trays per one treatment) of 28 cells and $70 \mathrm{~mL}$ volume of each. Tatsoi (Brassica rapa var. rosularis) was sown in a peat substrate (Profi 1, Durpeta, Lithuania) $(\mathrm{pH} 5-6)$. The average amounts of nutrients $\left(\mathrm{mg} \mathrm{L}^{-1}\right)$ in the substrate were: $\mathrm{N}-110 ; \mathrm{P}_{2} \mathrm{O}_{5}-50 ; \mathrm{K}_{2} \mathrm{O}-160$ supplemented with microelements $\mathrm{Fe}, \mathrm{Mn}, \mathrm{Cu}, \mathrm{B}$, $\mathrm{Mo}$, and $\mathrm{Zn}$. Electrical conductivity was $0.5-$ $0.7 \mathrm{mS} \mathrm{cm}$. Three seeds were sown into each cell and watered according to the demand. The period of experiment was 23 days from sowing $(20+3$ days of increased PPFD).

Non-destructive methods were used to evaluate the light effect of lighting treatments on tatsoi photosynthetic indices. The measurements of gas exchange were performed using a portable closed infrared gas analyser LI-6400XT (LI-COR, Lincoln, USA) with randomly selected, youngest fully expanded leaves on the last day of the treatment. The conditions for this measurement were set at 1000 $\mu \mathrm{mol} \mathrm{m} \mathrm{s}^{-2} \mathrm{~s}^{-1}$ PPFD, block temperature was $21^{\circ} \mathrm{C}, \mathrm{CO}_{2}$ concentration $\sim 400 \pm 6 \mu \mathrm{mol} \mathrm{s}^{-1}$ and $60-70 \%$ relative humidity.

Measurements of chlorophyll fluorescence were performed in closed environment growth chamber and fixed under LED lighting. In addition to this, before chlorophyll fluorescence measurements, all plants were dark adapted (Maxwell \& Johnson, 2000) for 40 minutes using black hood. Fluorometer OS5p (OptiSciences, USA) was used to measure maximum yield and yield in PSII (quantum of yield).

The maximum quantum of yield can be calculated from equation:

$$
Y_{m}=\frac{F_{V}}{F_{m}}
$$

where: $F v$ is variable fluorescence; $F m$ - maximal fluorescence (dark adapted sample)

Quantum of yield in PSII is calculated from equation:

$$
Y_{(I I)}=\frac{F_{m^{\prime}}-F}{F_{m}}
$$

where: $F^{\prime} m$ - maximal fluorescence (light adapted sample)

Chlorophyll, flavanols and nitrogen balance index (NBI) were measured by DUALEX 4 (Dualex

\section{The spectral composition and PPFD of LED light treatments}

\begin{tabular}{|c|c|c|c|c|c|c|c|c|c|c|}
\hline \multirow{3}{*}{ Light treatment } & \multicolumn{10}{|c|}{$\mathrm{PPFD}, \mu \mathrm{mol} \mathrm{m} \mathrm{m}^{-2} \mathrm{~s}^{-1}$} \\
\hline & \multicolumn{4}{|c|}{ during the growing } & \multicolumn{6}{|c|}{3 days before the harvest } \\
\hline & $\begin{array}{c}\text { B } 445 \\
\mathrm{~nm}\end{array}$ & $\begin{array}{c}\mathrm{R} 640 \\
\mathrm{~nm}\end{array}$ & $\begin{array}{c}\mathrm{R} 660 \\
\mathrm{~nm}\end{array}$ & $\begin{array}{c}\text { FR } 731 \\
\mathrm{~nm}\end{array}$ & $\begin{array}{c}\text { P/ } \\
\text { PPFD }\end{array}$ & $\begin{array}{c}\text { B } 445 \\
\mathrm{~nm}\end{array}$ & $\begin{array}{c}\mathrm{R} 640 \\
\mathrm{~nm}\end{array}$ & $\begin{array}{c}\mathrm{R} 660 \\
\mathrm{~nm}\end{array}$ & $\begin{array}{c}\text { FR } 731 \\
\mathrm{~nm}\end{array}$ & $\begin{array}{c}\mathrm{P} / \\
\mathrm{PPFD}\end{array}$ \\
\hline $\begin{array}{l}\text { Control PPFD } 200 \\
\mu \mathrm{mol} \mathrm{m}{ }^{-2} \mathrm{~s}^{-1}\end{array}$ & 20 & 88 & 88 & 4 & $16 / 200$ & 20 & 88 & 88 & 4 & $16 / 200$ \\
\hline $\begin{array}{l}\text { PPFD } 300 \mu \mathrm{mol} \\
\mathrm{m}^{-2} \mathrm{~s}^{-1}\end{array}$ & 30 & 132 & 132 & 6 & $16 / 300$ & 30 & 132 & 132 & 6 & $16 / 300$ \\
\hline $\begin{array}{l}\text { All up to PPFD } 300 \\
\mu \mathrm{mol} \mathrm{m} \mathrm{m}^{-2} \mathrm{~s}^{-1}\end{array}$ & 20 & 88 & 88 & 4 & $16 / 200$ & 30 & 132 & 132 & 6 & $16 / 300$ \\
\hline $\begin{array}{l}660 \mathrm{~nm} \text { to PPFD } 300 \\
\mu \mathrm{mol} \mathrm{m}{ }^{-2} \mathrm{~s}^{-1}\end{array}$ & 20 & 88 & 88 & 4 & $16 / 200$ & 20 & 88 & 188 & 4 & $16 / 300$ \\
\hline $\begin{array}{l}660 \mathrm{~nm} \text { to PPFD } 300 \\
\mu \mathrm{mol} \mathrm{m} \mathrm{s}^{-2} \mathrm{~s}^{-1} 24 \mathrm{~h}\end{array}$ & 20 & 88 & 88 & 4 & $16 / 200$ & 20 & 88 & 188 & 4 & $24 / 300$ \\
\hline
\end{tabular}

\footnotetext{
*FR - Far red, B - Blue, R - red, P - photoperiod, PPFD - photosynthetic photon flux density.
} 
Scientific, USA). Leaf reflectance indices: greenness (G) and photochemical reflectance index (PRI) were evaluated by leaf spectrometer CI-710 (CID, USA). Statistical analysis to evaluate significant differences was performed by an analysis of variance (ANOVA), the least significant difference (LSD) test at the $\mathrm{P} \leq 0.05$ level. Correlation analysis was conducted by statistical software package STATISTICA 10 (StatSoft, USA).

\section{Results and Discussion}

The results using non-destructive methods to evaluate photosynthetic performance and interaction between photosynthetic rates and fluorescence indices in tatsoi (Brassica rapa var. rosularis) are presented in Tables 2, 3 and 4. According to the data obtained, the photosynthetic parameters of tatsoi grown under PPFD levels at 200 and $300 \mu \mathrm{mol} \mathrm{m}^{-2} \mathrm{~s}^{-1}$ did not differ significantly (Table 2).

The plants grown under 200 and $300 \mu \mathrm{mol} \mathrm{m}^{-2} \mathrm{~s}^{-1}$ LED light intensities demonstrated the same total photosynthetic rate (Pn) $\left(12.41 \mu \mathrm{mol} \mathrm{CO} \mathrm{m}^{-2} \mathrm{~s}^{-1}\right)$. However, it was about $25 \%$ higher Pn than in tatsoi grown under the elevated red LED light $(660 \mathrm{~nm})$ intensity with total PPFD level at $300 \mu \mathrm{mol} \mathrm{m}^{-2} \mathrm{~s}^{-1}$. When the light intensity was increased in the three days pre-harvest stage, photosynthetic rate decreased, and the decrease was more pronounced in treatments where sole red light $(660 \mathrm{~nm})$ intensity was elevated. This is associated to decreased stomatal conductance and transpiration rates in red light $(660 \mathrm{~nm})$ enriched treatments (strong positive correlation between these indices) (Table 4).

The most pronounced effect on photosynthetic indices was determined in the treatment, where tatsoi in pre-harvest stage was illuminated with increased red light $(660 \mathrm{~nm})$ intensity for $24 \mathrm{~h}$ per day (Table $2)$. This resulted in significantly lower stomatal conductance (Gs) ( 3.29 times lower than control), intracellular $\mathrm{CO}_{2}(\mathrm{Ci})$ concentration $(\sim 1.1$ times lower than control), maximum quantum yield (Ym) $(\sim 1.26$ times lower than control), quantum yield of PSII $(\sim 1.23$ times lower than control) and $\mathrm{Pn}$ as well $(\sim 1.6$ times lower than control).

The highest $\mathrm{Ci}$ in tatsoi $\left(326.57 \mu \mathrm{mol} \mathrm{CO}_{2} \mathrm{~m}^{-2} \mathrm{~s}^{-1}\right)$, grown under all elevated LEDs to PPFD level at $300 \mu \mathrm{mol} \mathrm{m}{ }^{-2} \mathrm{~s}^{-1}$ three days before the harvest, was determined (not significant). The PPFD level at 300 $\mu \mathrm{mol} \mathrm{m} \mathrm{m}^{-2} \mathrm{~s}^{-1}$ led to the highest transpiration rate (Tr) as well (Table 2).

Considering gas exchange measurements, PPFD level at $300 \mathrm{PPFD} \mu \mathrm{mol} \mathrm{m} \mathrm{m}^{-2} \mathrm{~s}^{-1}$ had positive influence on tatsoi growth. Fluorescence measurements showed smaller differences among treatments, but in this case control treatments were performed most efficiently in photosystem II (PSII). The PPFD levels at 200 and $300 \mu \mathrm{mol} \mathrm{m}^{-2} \mathrm{~s}^{-1}$ showed the highest and reliable signal of resistance to environmental stress and efficient driving photosynthesis. About 25\% lower results were measured in the last three treatments. Maximum quantum yield (Ym) decreased gradually (significantly), when all light components were increased until $300 \mu \mathrm{mol} \mathrm{m} \mathrm{m}^{-2} \mathrm{~s}^{-1}$ three days before harvesting for 16 or 24 hours photoperiod (Table 2), while PS II only decreased significantly $(\sim 1.23$ times $)$ at $300 \mu \mathrm{mol} \mathrm{m} \mathrm{m}^{-2} \mathrm{~s}^{-1}$ with elevated red light $(660 \mathrm{~nm})$ component for 24 hours photoperiod. This could be associated with PS II inactivation and increased energy dissipation (Adams et al., 2013). Significant changes in ETR were not observed.

The effects of LED light treatments on photosynthetic parameters in tatsoi

Table 2

\begin{tabular}{|c|c|c|c|c|c|c|c|}
\hline Light treatment & $\begin{array}{c}\mathrm{Pn} / \mu \mathrm{mol} \\
\mathrm{CO}_{2} \mathrm{~m}^{-2} \mathrm{~s}^{-1}\end{array}$ & $\begin{array}{c}\mathrm{Gs} / \mathrm{H}_{2} \mathrm{O} \mathrm{mol} \\
\mathrm{m}^{-2} \mathrm{~s}^{-1}\end{array}$ & $\begin{array}{l}\mathrm{Ci} / \mu \mathrm{mol} \\
\mathrm{CO}_{2} \mathrm{~mol}^{-1}\end{array}$ & $\begin{array}{c}\mathrm{Tr} / \mathrm{mmol} \\
\mathrm{H}_{2} \mathrm{O} \mathrm{m}^{-2} \mathrm{~s}^{-1}\end{array}$ & Ym & $\mathrm{Y}\left({ }_{\mathrm{II}}\right)$ & $\begin{array}{c}\mathrm{ETR} / \mu \mathrm{mol} \\
\mathrm{e}^{-} \mathrm{m}^{-2} \mathrm{~s}^{-1}\end{array}$ \\
\hline $\begin{array}{l}\text { Control PPFD } 200 \mu \mathrm{mol} \\
\mathrm{m}^{-2} \mathrm{~s}^{-1}\end{array}$ & 12.41 & 0.46 & 322.95 & 1.07 & 0.67 & 0.69 & 31.00 \\
\hline PPFD $300 \mu \mathrm{mol} \mathrm{m}{ }^{-2} \mathrm{~s}^{-1}$ & 12.41 & 0.47 & 323.01 & 1.08 & 0.69 & 0.70 & 32.39 \\
\hline $\begin{array}{l}\text { All up to PPFD } 300 \mu \mathrm{mol} \\
\mathrm{m}^{-2} \mathrm{~s}^{-1}\end{array}$ & $10.01^{\mathrm{B}}$ & 0.32 & 326.57 & 0.90 & $0.58^{\mathrm{B}}$ & 0.62 & 37.42 \\
\hline $\begin{array}{l}660 \mathrm{~nm} \text { to PPFD } 300 \\
\mu \mathrm{mol} \mathrm{m} \mathrm{m}^{-2} \mathrm{~s}^{-1}\end{array}$ & $6.22^{\mathrm{B}}$ & $0.14^{\mathrm{B}}$ & 311.65 & $0.51^{\mathrm{B}}$ & $0.59^{\mathrm{B}}$ & 0.69 & 37.94 \\
\hline $\begin{array}{l}660 \mathrm{~nm} \text { to PPFD } 300 \\
\mu \mathrm{mol} \mathrm{m} \mathrm{m}^{-2} \mathrm{~s}^{-1} 24 \mathrm{~h}\end{array}$ & $7.76^{\mathrm{B}}$ & $0.14^{\mathrm{B}}$ & $294.91^{B}$ & $0.54^{\mathrm{B}}$ & $0.53^{\mathrm{B}}$ & $0.56^{\mathrm{B}}$ & 28.34 \\
\hline $\mathrm{LSD}_{0.05}=$ & 2.71 & 0.22 & 17.92 & 0.32 & 0.06 & 0.07 & 8.05 \\
\hline
\end{tabular}

*Pn - Photosynthetic rate, $\mathrm{Gs}$ - Stomatal conductance, $\mathrm{Ci}$ - Intercellular $\mathrm{CO}_{2}$ concentration, $\mathrm{Tr}-\mathrm{Transpiration}$ rate, $\mathrm{Ym}$ - Maximum quantum yield, $\left.\mathrm{Y}_{\mathrm{II}}\right)$ - Quantum yield of PS II, ETR - Electron transport rate

$\mathrm{B}$ - The value is significantly $(\mathrm{P} \leq 0.05)$ lower than control. 
Table 3

The effects of LED light treatments on leaf pigments and optical properties parameters in tatsoi

\begin{tabular}{|l|c|c|c|c|c|}
\hline \multicolumn{1}{|c|}{ Light treatment } & $\begin{array}{c}\text { Chlorophyll } \\
\text { index }\end{array}$ & $\begin{array}{c}\text { Flavanols } \\
\text { index }\end{array}$ & Greeness index & NBI & PRI \\
\hline Control PPFD $200 \mu \mathrm{mol} \mathrm{m}^{-2} \mathrm{~s}^{-1}$ & 37.44 & 0.81 & 49.21 & 1.41 & -0.04 \\
\hline PPFD $300 \mu \mathrm{mol} \mathrm{m}^{-2} \mathrm{~s}^{-1}$ & $\mathbf{3 2 . 3}^{\mathbf{B}}$ & $\mathbf{1 . 3 3}^{\mathbf{A}}$ & $\mathbf{2 5 . 3 6}^{\mathbf{B}}$ & 1.38 & $\mathbf{- 0 . 0 6}^{\mathbf{B}}$ \\
\hline All up to PPFD $300 \mu \mathrm{mol} \mathrm{m} \mathrm{s}^{-1}$ & $\mathbf{2 8 . 7 5 ^ { \mathbf { B } }}$ & 0.98 & $\mathbf{3 2 . 7 4}^{\mathbf{B}}$ & 1.44 & $\mathbf{- 0 . 0 5}^{\mathbf{B}}$ \\
\hline $660 \mathrm{~nm}$ to PPFD $300 \mu \mathrm{mol} \mathrm{m}^{-2} \mathrm{~s}^{-1}$ & 38.85 & 0.94 & 44.25 & 1.24 & $-0.05^{\mathbf{B}}$ \\
\hline $660 \mathrm{~nm}$ to PPFD $300 \mu \mathrm{mol} \mathrm{m} \mathrm{s}^{-1} 24 \mathrm{~h}$ & 33.23 & $\mathbf{1 . 1 3}^{\mathbf{A}}$ & $\mathbf{3 0 . 6 2}^{\mathbf{B}}$ & 1.42 & -0.04 \\
\hline $\mathrm{LSD}_{0.05}=$ & 4.67 & 0.23 & 11.11 & 0.20 & 0.01 \\
\hline
\end{tabular}

*NBI - Nitrogen balance index, PRI - Photochemical reflectance index

$A-$ The value is significantly $(\mathrm{P} \leq 0.05)$ higher than control; $\mathrm{B}$ - The value is significantly $(\mathrm{P} \leq 0.05)$ lower than control

Plants grown under increased red light intensity

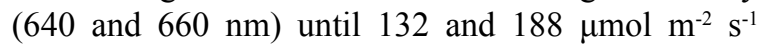
were affected by photoinhibition. Instantaneous photosynthesis and fluorescence parameters resulted in decreased response comparing with lower light intensity $-200 \mu \mathrm{mol} \mathrm{m} \mathrm{m}^{-2} \mathrm{~s}^{-1}$ PPFD. Light excess is a restrictive factor for efficient photosynthetic process and have a negative effect on photosynthesis system acclimatisation causing photoinhibition (Powles, 1984). In this case, $200 \mu \mathrm{mol} \mathrm{m} \mathrm{m}^{-2} \mathrm{~s}^{-1}$ PPFD was sufficient for efficient photosynthetic process in tatsoi.

The results of non-destructive leaf pigments and optical properties measurement confirm that different lighting conditions even for short three-day preharvest treatment have a significant effect on plant performance (Table 3).

Leaf pigments and optical properties analysis in tatsoi (Table 3) showed that light quantity and preharvest exposure three days before harvesting had a significant effect on plants. Chlorophyll and greenness indexes decreased ( $\sim 1.16$ and 1.94 times) when PFFD was $300 \mu \mathrm{mol} \mathrm{m} \mathrm{m}^{-2} \mathrm{~s}^{-1}$ or $\sim 1.3$ and $\sim 1.5$ times when all light components were elevated until $300 \mu \mathrm{mol} \mathrm{m} \mathrm{m}^{-2} \mathrm{~s}^{-1}$ three days before harvesting. However, flavanols index significantly increased when PPFD was 300 $\mu \mathrm{mol} \mathrm{m} \mathrm{m}^{-2} \mathrm{~s}^{-1}$ at 16 hours photoperiod or 24 hours with elevated red light (660 nm) comparing with the control treatment. It can be claimed that rapid chlorophyll index degradation is related to flavanol index increase via changes in plants senescence physiology and reflect trends in photosynthetic activity (Mattilla et al., 2018). Increased all light components or just red light (660 nm) intensity at 16 hours photoperiod had a significant effect on PRI reduction. However, the control treatment did not show differences comparing with other treatments. To sum up, it can be useful to apply longer photoperiod in order to promote photoprotective system reactions and xantophyll cycle changes.

Table 4

Correlation among photosynthetic parameters in tatsoi, grown under various LED light treatments

\begin{tabular}{|l|c|c|c|c|c|c|}
\hline \multicolumn{1}{|c|}{ Variable } & Pn & Gs & Tr & Ym & Y ( $\left(_{\text {II }}\right)$ & ETR \\
\hline Gs & $\mathbf{0 . 8 8}$ & & & & & \\
\hline Tr & $\mathbf{0 . 9 8}$ & $\mathbf{0 . 8 3}$ & & & & \\
\hline Ym & $\mathbf{0 . 5 4}$ & $\mathbf{0 . 5 8}$ & $\mathbf{0 . 5 5}$ & & & \\
\hline Y( $\left.{ }_{\text {II }}\right)$ & 0.24 & $\mathbf{0 . 3 2}$ & $\mathbf{0 . 2 9}$ & 0.25 & & \\
\hline ETR & -0.09 & -0.07 & -0.02 & -0.5 & 0.03 & \\
\hline
\end{tabular}

*Pn - Photosynthetic rate, Gs - Stomatal conductance, Tr - Transpiration rate, Ym - Maximum quantum yield, $\mathrm{Y}\left({ }_{\mathrm{II}}\right)$ - Quantum yield of PS II, ETR - Electron transport rate 
The lower chlorophyll index and photochemical reflectance index comparing in tatsoi, cultivated under PPFD $300 \mu \mathrm{mol} \mathrm{m}^{-2} \mathrm{~s}^{-1}$, compared to PPFD $200 \mu \mathrm{mol} \mathrm{m} \mathrm{m}^{-2} \mathrm{~s}^{-1}$ confirm the obtained trend in photosynthetic rate. It shows that PPFD $200 \mu \mathrm{mol} \mathrm{m}^{-2} \mathrm{~s}^{-1}$ is sufficient light quantity for efficient photosynthesis and productivity of tatsoi and in economic cultivation system; there is no need to waste energy increasing PPFD to $300 \mu \mathrm{mol} \mathrm{m}^{-2} \mathrm{~s}^{-1}$. Increased flavonol index in PPFD $300 \mu \mathrm{mol} \mathrm{m}^{-2} \mathrm{~s}^{-1}$ treatment and $660 \mathrm{~nm}$ to PPFD $300 \mu \mathrm{mol} \mathrm{m} \mathrm{m}^{-2} \mathrm{~s}^{-1}$ treatment of $24 \mathrm{~h}$, show the photoprotective reactions of tatsoi antioxidant system. The reduced NBI index in higher PPFD $300 \mu \mathrm{mol} \mathrm{m}^{-2} \mathrm{~s}^{-1}$ during the cultivation stage and pre-harvest increased light intensity treatments show the excess light effect on the nitrogen assimilation processes.

The obtained results propose that excess light intensity is not efficiently utilized for photosynthetic processes and $200 \mu \mathrm{mol} \mathrm{m} \mathrm{m}^{-2} \mathrm{~s}^{-1}$ light intensity for growing period is sufficient for tatsoi cultivation. The pre-harvest treatment with an increased level of LED light also results in reduced photosynthetic parameters. This might be associated to mild photo-stress conditions and tatsoi adaptations to increased light intensity and/ or shifted proportions of light spectral quality.

In addition to this experiment, the variability and correlations among all photosynthetic indices showed strong differences between instantaneous photosynthetic intensity and chlorophyll fluorescence values (Table 4). However, only among Pn, Gs and Tr strong positive correlations ( $r>0.7)$ were obtained comparing all values. According to the previous studies, these linkages were determined between photosynthesis and chlorophyll fluorescence indexes as well (Flexas et al., 2000; Zarco-Tejada et al., 2013; Yang et al., 2017).

These results agree with the statements of other authors that pre-harvest higher LED light treatments can evoke the response of antioxidant protective system and, therefore, resulted in an increased nutritional value of green vegetables (Samuoliene et al., 2012b; Zhou, Liu, \& Yang, 2012; Wanlai, Liu, \& Qichang, 2013). Samuoliene et al., (2009) proposed that the reduction of nitrates and increased ascorbic acid contents could be associated to provoked natural senescence and remobilization of nutrients. Our study showed that elevated light intensity three days before harvesting suppressed main photosynthetic indices in tatsoi, and $200 \mu \mathrm{mol} \mathrm{m} \mathrm{m}^{-2} \mathrm{~s}^{-1}$ is sufficient for the cultivation process. Further studies should be performed, seeking to balance the light conditions and strategies for different species and varieties of green leafy vegetables, aiming for increased economic efficiency of lighting, optimal photosynthetic performance of plants and high nutritional value.

\section{Conclusions}

A higher intensity of LED lighting of PPFD 300 $\mu \mathrm{mol} \mathrm{m} \mathrm{m}^{-2} \mathrm{~s}^{-1}$ was not superior for plant photosynthetic performance, according to the measured indices, compared to PPFD $200 \mu \mathrm{mol} \mathrm{m} \mathrm{m}^{-2} \mathrm{~s}^{-1}$ light intensity. For efficient photosynthesis, it is enough to have $16 \mathrm{~h}$ photoperiod and PPFD $200 \mu \mathrm{mol} \mathrm{m}^{-2} \mathrm{~s}^{-1}$ light intensity for tatsoi. Plants treated under elevated PPFD can be affected by stress. Increased pre-harvest lighting intensity resulted in suppressed photosynthetic and optical leaf indices in tatsoi. Increased red light intensity of $660 \mathrm{~nm}$ three days before the harvesting reduced photosynthetic indices in plants. Tatsoi experienced mild photo stress conditions resulting in adaptive changes: increased flavanols, reduced chlorophyll and PRI.

\section{Acknowledgements}

This project was funded by a grant No. 09.3.3-LMT-K-712-03-0009 from the Research Council of Lithuania.

\section{References}

1. Adams III, W.W., Muller, O., Cohu, M.C., \& Adams, D.B. (2013). May photoinhibition be a consequence, rather than a cause, of limited plant productivity? Photosynthesis Research. 117(1-3), 31-44. DOI: 10.1007/s11120-013-9849-7.

2. Bliznikas, Z., Zukauskas, A., Samuolienè, G., Viršilè, A., Brazaitytè, A., Jankauskienè, J., Duchovskis, P., \& Novičkovas, A. (2012). Effect of supplementary pre-harvest LED lighting on the antioxidant and nutritional properties of green vegetables. Acta Horticulturae. 939(10), 85-91. DOI: 10.17660/ ActaHortic.2012.939.10.

3. Bassi, D., Menossi, M., \& Mattiello, L. (2018). Nitrogen supply influences photosynthesis establishment along the sugarcane leaf. Scientific Reports. 8(2327), 1-13. DOI: 10.1038/s41598-018-20653-1.

4. Carvalho, D., \& Folta, M. (2014). Environmentally Modified Organisms - Expanding Genetic Potential with Light. Critical Reviews in Plant Sciences. 33(6), 458-508. DOI: 10.1080/07352689.2014.929929.

5. Cocetta, G., Casciani, D., Bulgari, R., Musante, F., Kolłon, A., Rossi, M., \& Ferrante, A. (2017). Light use efficiency for vegetables production in protected and indoor environments. The European Physical Journal Plus. 132(43), 1-15. DOI: 10.1140/epjp/i2017-11298-x. 
6. Flexas, J., Briantais, M.J., Cerovic, Z., Medrano, H., \& Moya, I. (2000). Steady-State and Maximum Chlorophyll Fluorescence Responses to Water Stress in Grapevine Leaves: A New Remote Sensing System. Remote Sensing of Environment. 73(3), 283-297. DOI: 10.1016/S0034-4257(00)00104-8.

7. Hall, O.D., \& Rao, K.K. (1999). Photosynthesis. (6th ed.). Cambridge: Cambridge University Press.

8. Yang, H., Yang, X., Zhang, Y., Heskel, A.M., Lu, X., Munger, W.J., Sun, S., \& Tang, J. (2017). Chlorophyll fluorescence tracks seasonal variations of photosynthesis from leaf canopy in a temperate forest. Global Change Biology. 23, 2874-2886. DOI: 10. 1111/gcb.13590.

9. Jansen Marcel, A.K., Hectors, K., O’Brien M.N., Guisez, Y., \& Potters, G. (2008). Plant stress and human health: Do human consumers benefit from UV-B acclimated crops? Plant Science. 175(4), 450-458. DOI: 10.1016/j.plantsci.2008.04.010.

10. Kang, H.J., KrishnaKumar, S., Atulba, S.L.S., Jeong, R.B., Hwang, J.S. (2013). Light Intensity and Photoperiod Influence on the Growth and Development of Hydroponically Grown Leaf Lettuce in a Closed-type Plant Factory System. Horticulture Environment Biotechnology. 54(6), 501-509. DOI: 10.1007/s13580-013-0109-8.

11. Kubota, C., Kroggel, M., Both, J.A., Burr, F.J., \& Whalen, M. (2016). Does supplemental lighting make sense for my crop? - empirical evaluations. ISHS Acta Horticulturae 1134 VIII International Symposium on Light in Horticulture. 22 - 26 May, 2016. East Lansing, MI (United States of America) (403-412). DOI: 10.17660/ActaHortic.2016.1134.52.

12. Mattila, H., Valev, D., Havurinne, V., Khorobrykh, S., Virtanen, O., Antinluoma, M., Mishra, K., \& Tysstjärvi, E. (2018). Degradation of chlorophyll and synthesis of flavonols during autumn senescence-the story told by individual leaves. AoB Plants. 10(3), 1-13. DOI: 10.1093/aobpla/ply028.

13. Maxwell, K., \& Johnson, N. (2000). Chlorophyll fluorescence-a practical guide. Journal of Experimental. Botany. 51(345), 659-668. DOI: 10.1093/jexbot/51.345.659.

14. Muhoz, R., \& Quiles, J.M. (2003). Studying the effect of light quality on the size of the photosystem II light harvesting complex. Journal of Biological Education. 38(1), 36-38. DOI: 10.1080/00219266.2003.9655894.

15. Nakaji, T., Oguma, H., \& Fujinuma, Y. (2006). Seasonal changes in the relationship between photochemical reflectance index and photosynthetic light use efficiency of Japanase larch needles. International Journal of Remote Sensing. 27(3), 493-509. DOI: 10.1080/01431160500329528.

16. Olle, M., \& Viršilè, A. (2013). The effects of light-emitting diode lighting on greenhouse plant growth and quality. Agricultural and food science. 22, 223-234. DOI: 10.23986/afsci.7897.

17. Powles, B.S. (1984). Photoinhibition of photosynthesis induced by visible light. Annual Review of Plant Physiology. 35, 15-44. DOI: 10.1146/annurev.pp.35.060184.000311.

18. Rouphael, Y., Kyriacou, C.M., Petropoulos, A.S., De Pascale, S., \& Colla, G. (2018). Improving vegetable quality in controlled environments. Scientia Horticulturae. 234, 278-289. DOI: 10.1016/j. scienta.2018.02.033.

19. Samuolienè, G., Brazaitytè, A., Sirtautas, R., Novičkovas, A., \& Duchovskis, P. (2012a). The effect of supplementary LED lighting on antioxidant and nutritional properties of lettuce. Acta Horticulturae. 952(106), 835-841. DOI: 10.17660/ActaHortic.2012.952.106.

20. Samuolienė, G., Sirtautas, R., Brazaitytė, A., Viršile, A., \& Duchovskis, P. (2012b). Supplementary redLED lighting and the changes in phytochemical content of two baby leaf lettuce varieties during three seasons. Journal of Food, Agriculture and Environment. 10(3-4), 701-706.

21. Samuolienė, G., Urbonavičiūte, A., Duchovskis, P., Bliznikas, Z., Vitta, P., \& Žukauskas, A. (2009). Decrease in nitrate concentration in leafy vegetables under a solid-state illuminator. Hortscience. 44(7), 1857-1860.

22. Samuolienė, G., Brazaitytè, A., Sirtautas, R., Novičkovas, A., \& Duchovskis, P. (2011). Supplementary red-LED lighting affects phytochemicals and nitrate of baby leaf lettuce. Journal of Food, Agriculture and Environment. 9(3-4), 271-274.

23. Singh, D., Basu, C., Meinhardt-Wollweber, M., \& Roth, B. (2015). LEDs for energy efficient greenhouse lighting. Renewable and Sustainable Energy Reviews. (49), 139-147. DOI: 10.1016/j.rser.2015.04.117.

24. Sun, J., Ye, M., Peng, S., \& Li, Y. (2016). Nitrogen can improve the rapid response of photosynthesis to changing irradiance in rice (Oryza sativa L.) plants. Scientific Reports. 6(31305), 1-10. DOI: 10.1038/ srep31305.

25. Wanlai, Z., Liu, W., \& Qichang, Y. (2013). Reducing nitrate content in lettuce by pre-harvest continuous light delivered by red and blue light emitting diodes. Journal of Plant Nutrition. 36(3), 481-490. DOI: 10.1080/01904167.2012.748069. 
26. Wojciechowska, R., Długosz-Grochowska, O., Kołton, A., \& Župnik, M. (2015). Effects of LED supplemental lightning on yield and some quality parameters of lamb's lettuce grown in two winter cycles. Scientia Horticulturae. 187, 80-86. DOI: 10.1016/j.scienta.2015.03.006.

27. Zarco-Tejada, J.P., Catalina, A., González, R.M., \& Martín, P. (2013). Relationships between net photosynthesis and steady-state chlorophyll fluorescence retrieved from airborne hyperspectral imagery. Remote Sensing of Environment. DOI: 10.1016/j.rse.2013.05.011.

28. Zhen, S., \& Van Iersel, W.M. (2017). Far-red light is needed for efficient photochemistry and photosynthesis. Journal of Plant Physiology. 209, 115-122. DOI: 10.1016/j.jplph.2016.12.004.

29. Zhou, L.W., Liu, K.W., \& Yang, C.Q. (2012). Quality changes in hydroponic lettuce grown under preharvest short-duration continuous light of different intensities. The Journal of Horticultural Science and Biotechnology. 87(5), 429-434. DOI: 10.1080/14620316.2012.11512890. 